\title{
Leprosy in Burma
}

\author{
TIN SHWE \\ Medical Team Leader, Yame Thin District, Burma Leprosy Campaign
}

\begin{abstract}
A brief history of the spread of leprosy into Burma is outlined and the present prevalence of the disease is discussed. In addition, a short epidemiology of the disease, the Leprosy Control Project in Burma, and the present role of leprosy colonies and institutions in Burma are presented.
\end{abstract}

\section{SPREAD OF LEPROSY}

No definite records exist regarding the origin and spread of leprosy in Burma, although there are indications that the disease may have been imported from India and China. During the past 900 years the Chinese have invaded Burma more than once and many Chinese remained in Burma. More recently, merchants from India have visited Burma for purposes of trade. Both Chinese and Indians live generally in the larger towns of Burma. Hence, leprosy has been more prevalent near the old Burmese capital towns.

After the first Anglo-Burmese war (1826) British traders established themselves in the coast areas and began exporting rice to the West. After the second Anglo-Burmese war (1852) and the opening of the Suez Canal (1868) there was a great increase in the amount of rice exported, and this crop depended for its cultivation on an influx of people from upper to lower Burma. Many Indians also came to Burma and their numbers doubtless included some with leprosy. Thus leprosy, which had hitherto been localized to the larger towns, began to spread into the villages.

The second large migration of Burmese took place during the Second World War (1941-45). This time the direction of movement was from lower Burma to upper Burma.

The third migration occurred immediately after the war, because of the unsettled state of the outlying areas; the movement was therefore from rural to urban areas, in other words

*Received for publication February, 1970. from areas relatively free of leprosy to areas where leprosy was already present. These successive migrations have had their influence on the spread of leprosy in the country (Dr. Kyaw Lwin, personal communication).

\section{PREVALENCE}

The earliest records of leprosy as derived from census reports indicate that the prevalence of the disease in lower Burma in $1867-72$ was 1.16 per 1000 , in 1881 it was 0.69 , and in $1891,0.63$ per 1000. According to the 19:31 census there were 11,000 cases of leprosy in the whole country.

Leprosy surveys carried out between 1932 and 1941 in 9 districts of Burma, indicated an average prevalence of 17.4 per 1000 of the population (Dharmendra, 1953).

In 1951, Dr. Dharmendra (WHO consultant) estimated the prevalence of leprosy over the whole of Burma to be about 5 per 1000 , or about 100,000 cases for the whole country. In 1953, a WHO survey team (WHO, 1957) estimated the leprosy prevalence in hyperendemic areas in Shwe Bo and Myin Gyan districts in Central Burma, as 25 per 1000 (equivalent to 591,600 in a population of $2: 3,664,000$ ) - but this was an overestimate.

The Burma Leprosy Campaign, begun in 1952, registered a $n$ increasing number of patients, and in 1969, the total number registered was 209,706. The Campaign had now covered most of Burma. The probable prevalence of leprosy throughout the country is in the region of 10 per 1000 , or 250,000 cases in all. (Estimate 


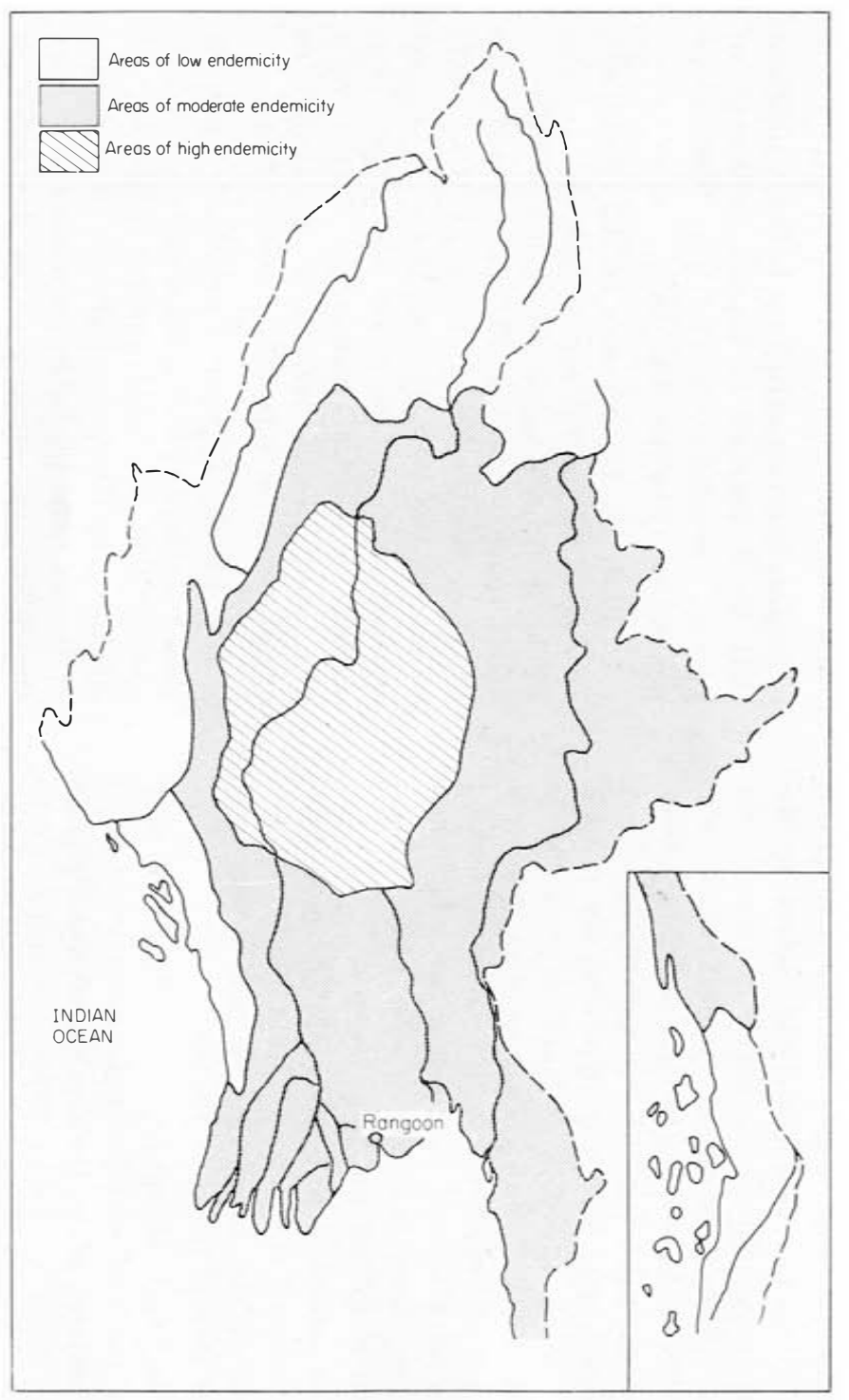

FIG. 1

Distribution of leprosy in Burma.

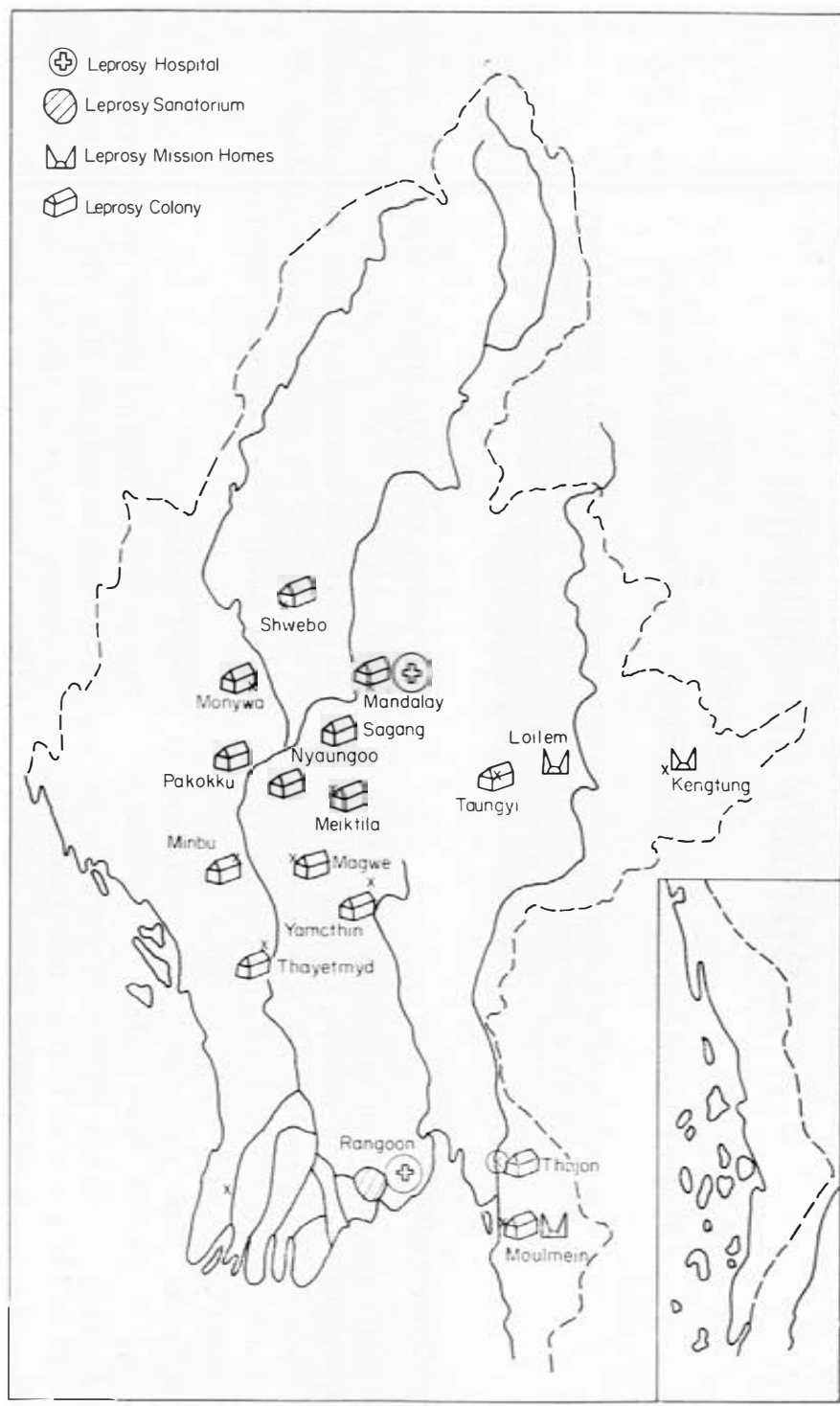

FIG. 2

Leprosy hospitals, homes and colonies in Burma. 
of the Iirectorate of Health Services, Union of Burma.) These figures from Burma are indeed high when compared with neighbouring countries such as Ceylon (1963) 0.97 per 1000, Pakistan (1963) 2.23, China Mainland (1960) 3.42, India (1962) 5.56, Thailand (1963) 6.94, and Nepal (1962) 7.8 per 1000.

\section{DISTRIBUTION}

No part of the country is free from the disease, but its distribution is not uniform. The dry zone of Central Burma with an annual rainfall of below $4 \mathrm{in}$. $(10 \mathrm{~cm})$ has the highest prevalence rate (up to 40 to 50 per 1000 ). The coastal areas (Arakan Division, the lower part of Tenesseram Division) and the Chin Special Division (the hilly area bordering on India) have low rates, less than 5 per 1000 . The remaining areas (Shan States, Irrawaddy Division, and areas outside the dry zone) have moderate rates.

The proportion of patients with lepromatous leprosy is approximately $25 \%$ in Burma, a figure comparable with that found in other Mongolian races, but distinctly higher than that in India $(20 \%)$ or Africa (6 to $10 \%$ ).

\section{FREQUENCY OF DISABILITIES}

There is a high incidence of disability among leprosy patients in Burma, with rates of 44.66 and $52.72 \%$ in the Shwe Bo and Myin Gyan Districts respectively, compared with a rate of $23.4 \%$ in Northern Nigeria. The figure for Burma, however, may be related both to the type of leprosy and the size of the untreated backlog of leprosy sufferers.

\section{LEPROSY CONTROL PROJECT OF BURMA}

Before World War II there was only one leprosy officer in the Department of Health and he was responsible for the leprosy campaign in the whole of the country. After the war, in 1951, assistance from the United Nations was forthcoming. Dr. Dharmendra visited Burma as consultant for the $\mathrm{WHO}$, and as a result, the Burmese Government made plans to begin leprosy control, which was inaugurated the following year with the help of WHO.
In 1952-3 The Central Leprosy Institute (known as the "Special Skin Clinic") was established in Rangoon near Rangoon General Hospital, and at once instituted courses of training for medical and paramedical workers. In 1953 a Government Leprosy Sanatorium with accommodation for 450 patients was inaugurated at Htauk Kyant. In 1957-8, with the co-operation of WHO and UNICEF, an intensive programme for the control of leprosy was drawn up and implemented initially in pilot areas in the states of Shwe Bo, Myin Gyan, and Shan. On the basis of the experience gained in these pilot areas, the programme for leprosy control has been expanded to other hyperendemic areas. Apart from the actual treatment of leprosy patients, sources of contagion are traced. In the Magwe pilot area, the team leader (who is a medical officer) has charge of 18,000 patients; he is assisted by 3 inspectors, one assistant inspector, and 51 junior leprosy workers, and has at his disposal 4 jeeps, 5 motor cycles, and 48 bicycles.

From 1956 onwards, UNICEF has helped the leprosy campaign with equipment and transport. In 1964-5 the following 3 organizations assisted the Burma Leprosy Control Programme by contributing $\$ 150,000$ (U.S.) through WHO to pay for additional staff over a period of 5 year's, namely: (1) International Committee for Assistance to Leprosy of the Order of Malta, (2) Committee of Emmaus Suisse (Switzerland), and (3) Deutsches Hilfswerk (Germany). A 5-year programme (1963-8) was drawn up for leprosy control throughout the country.

In July, 1966, the Burmese Government established 2 leprosy hospitals (after nationalizing leprosy asylums in Rangoon and Mandalay) to serve as the main centres of the campaign.

The leprosy control work in Burma, which has now been expanded to 34 project areas covering almost the whole of Burma, is under the Assistant Director of Health Services, Rangoon. The main objects of these field units are to discover new cases of leprosy and to provide regular treatment for all registered patients either through leprosy clinics or by house-to-house visits. 
By March, 1968, 181,524 leprosy patients had been registered, of whom 172,616 (or $76 \%$ of the then estimated total number of patients in Burma) were under regular treatment; $85 \%$ of them are in the rural areas, where the bulk of the population lives (see Fig. 1).

\section{LEPROSY COLONIES AND INSTITUTIONS IN BURMA}

\section{Before World War II}

After the annexation of Burma by the British Government in 1885 the missionaries also came along with the new government officials. The Roman Catholic Mission established 4 large asylums for leprosy patients and the Mission to Lepers (International and Interdenominational) established a further 3. In 19:30 the Government appointed one special leprosy officer for Burma. He was sent for training under Dr. Ernest Muir at the Calcutta School of Hygiene and Tropical Medicine. In those days "isolation of infected lepers" was the only measure advocated to all leprosy workers to check the spread of the disease. On his return from Calcutta the leprosy officer organized the establishment of leprosy colonies in various districts of Burma. In order to establish these colonies the Burma branch of the then British Empire Leprosy Relief Association (now LEPRA) gave a cash grant of Rs 500 initially and subsequently an offer of one rupee per head per month. This kind of financial help stimulated the formation in many localities of District Leprosy Relief Associations and led eventually to the establishment of leprosy colonies in 9 districts.

\section{After World War II}

After the war 6 large leprosy colonies belonging to the missionaries were re-established as soon as possible. The Baptist Mission modernized their colonies to form 2 leprosy homes and hospitals. Similarly the voluntary associations had also re-established 17 smaller colonies for leprosy patients. The Government also established a leprosy sanatorium near Rangoon (see Fig. 2).
In 196:3 the total number of patients living in leprosy colonies from all over Burma was 3681 , which constitute only $1.5 \%$ of all the known patients in the country. Keeping this small percentage of leprosy patients in colonies will have no significant effect on the control of leprosy and at the same time it is a big burden on the Government. Moreover, many of the patients in these colonies later lost contact with their families and friends and became permanent dependants of the colonies, thus creating further social and other rehabilitation problems.

Realizing the innate difficulties and drawbacks the Government therefore decided to limit the admission of new patients into these colonies from the year 1963. On 22 July the Government nationalized the leprosy asylums at Rangoon and Mandalay and established 2 leprosy hospitals, which are now serving as research and training centres for the Burma Leprosy Campaign.

\section{ACKNOWLEDGEMENTS}

I express my gratitude to Dr. U Kyaw Lwin, Assistant Director (Leprosy), Directorate of Health Services, Burma, under whose guidance this paper was prepared.

I also wish to express my thanks to the following, with whose help all the data used in this paper were obtained: Dr. U Khin Mg Gyi, M.S. Leprosy Hospital, Mandalay; Dr. U Hla Toe, Regional Leprosy Officer, Rangoon; Dr. U Pe Khin, M.S. Leprosy Hospital, Rangoon; Dr. W. Edwards, M.S. Leprosy Home and Hospital, Moulmein; Dr. U Saing of Htauk Kyant Leprosy Institute; and Mr. Saw Thar Phwe of the Directorate of Health Services.

\section{REFERENCES}

BECHELLI, L. M. and MARTINEZ DOMINGUEZ, v. (1966). A guide to leprosy control. World Health Organization, Geneva.

DHARMENDRA, A. (1953). Report on leprosy and its control in Burma. World Health Organization Leprosy Report: Rangoon: Government Printing Press.

kO GYI, U. and ko LAY, U. (1967). The Eyes in Noninstitutional Cases of Leprosy. Rangoon: Government Printing Press. 
Report of Leprosy Commission in India, 1890-91 (1893). Calcutta: Government Printing Press.

Reprorts on State of Public Health in Burma 1938, 1947, 1948, 1950. Rangoon: Government Printing Press.

SEIN BAN HONORABLE, U. (1956). Ten years of health progress in Burma. Burma med. .J. 4, 36.
THA SAING, U. (1951). Type distribution of leprosy in Burmans and Indians. Lepr. India 23, 103.

WORLD HEALTH ORGANIZATION ADVISORY TEAM (1957). Report on Leprosy Survey in Burma, January to June, 1953. World Health Organization Regional Office, South East Asia.

WORLD HEALTH ORGANIZATION. Rehabilitation of leprosy sufferers. Ten million cases of leprosy in the world today. Med. .J. Malaya 1960, 15, No. I. 